This is a self-archived version of an original article. This version may differ from the original in pagination and typographic details.

Author(s): Elmgren, Heidi

Title: Merit-based exclusion in Finnish music schools

Year: 2019

Version: Accepted version (Final draft)

Copyright: @ 2019 SAGE Publications

Rights: In Copyright

Rights url: http://rightsstatements.org/page/lnC/1.0/?language=en

Please cite the original version:

Elmgren, H. (2019). Merit-based exclusion in Finnish music schools. International Journal of Music Education, 37(3), 425-439. https://doi.org/10.1177/0255761419843990 


\title{
Merit-based Exclusion in Finnish Music Schools ${ }^{123}$
}

\begin{abstract}
:
In this article I analyse merit-based exclusion in Finnish music schools for children and young people. I base my study on my earlier research on meritocracy and written data collected online from current and former music school students in the autumn and winter of 2015-2016. I am able to show there are implicit and explicit merit-based hierarchies in the music school. The hierarchies and exclusion are shown to be connected to the institution's meritocratic features. As the hierarchies are merit-based, it is hard to question them. The hierarchies justify excluding students from certain practices such as performances. These practices are in fact learning opportunities, as has been established by earlier research. In addition to this, the hierarchies also influence students' view of their potential and this combined with limited learning opportunities hinders their development. The hierarchies thus produce self-fulfilling prophecies of the students' advancement. This is how the meritocratic system can in fact produce the failure it pretends only to reflect.
\end{abstract}

\section{Introduction}

The article analyses merit-based exclusion in Finnish music schools for children and young people. I base my study on my earlier research on meritocracy (Elmgren, 2015; 2018) and written data collected online from current and former music school students in the autumn and winter of 20152016. I analyse the data from the point of view of theory-driven qualitative content analysis (Alasuutari, 2012), using my previously built framework on meritocracy as the theoretical foundation. I ask whether there are implicit or explicit hierarchies in the music school, and what they are based on, and study the students' experiences of hierarchies and the exclusion they cause. I aim to show that the hierarchies and exclusion are connected to the institution's meritocratic features. 'Meritocracy' usually refers to a form of government. In this article, I use the term in its adjectival form as a descriptive concept that refers to practices and mindsets aimed at distributing recognition, other social goods and/or resources based on individuals' merits.

\footnotetext{
${ }^{1}$ I want to thank Anita Kangas, M arja-Leena Juntunen, Alain Caillé, Emmanuel Renault, Jenny Säilävaara, Tiina Sihto and Armi M ustosmäki for their insightful comments and encouragement during the writing of this article.

${ }^{2}$ This article is part of my compilation dissertation that concerns principles of meritocracy and meritocratic practices from a philosophical point of view. This fourth and concluding article is an empirical application of theoretical work I have prepared in my other articles.

${ }^{3}$ This publication has been undertaken as part of the ArtsEqual research initiative, financed by the Academy of Finland's Strategic Research Council of the Academy of Finland from its Equality in Society program (project number 293199).
} 


\subsection{The Finnish Music School System}

By music school, I refer to partly state-funded Finnish institutions of musical education for children and the young (approximately 6-18-year-olds) that offer music studies as an extracurricular activity and form part of the Basic Education in the Arts. There are 96 music schools in Finland (Suomen musiikkioppilaitosten liitto 2017). In total, $4.6 \%$ of 7-19-year-olds take part in music education (in some parts of Finland, the participation rate is as high as 7.9\%) (Aluehallintovirasto, 2012). ${ }^{4}$ The Association of Finnish Music Schools is part of the European Music School Union (Riediger, Eicker, \& Koops, 2010).

The music schools follow the national core curriculum for the Basic Education in the Arts ${ }^{5}$, which is a curriculum framework formulated by the Finnish National Agency for Education (Alt, Enakimio, Meriluoto, and Rodionoff, 2017). Music schools have a strong standing in the Finnish art education and several laws regulate their status. The first law concerning music schools is from 1968 (see Kangas \& Halonen, 2015, pp. 199-200). The Basic Education in the Arts includes different fields of the arts and is, by law, target-oriented, advancing from one level to another and organized primarily for children and the young. In addition, it gives the student the ready ability to express oneself and apply for professional training in one's respective field (Law concerning basic education in the arts, 1998/633.)

In music schools, students advance through course examinations to complete diplomas for their studies. Education is carried out as instrument lessons (most often one-on-one tuition) and other related studies. The schools create the curricula themselves within the national framework. Most of the music schools concentrate on Western classical music, with some of them also teaching a socalled pop/jazz curriculum as well as the classical one. In many music schools, students are chosen based on an entrance examination. The acceptance rate is approximately 50\% (Kangas \& Halonen, 2015, p. 203).

\footnotetext{
${ }^{4}$ The basic education of arts in music is also provided outside music schools (e.g. in community colleges), but music schools are the focus of this study.

${ }^{5}$ On should pay attention that the basic education (the 'regular' school system) and basic education in the arts (of which music schools are a part) are two distinct systems. Music is taught in Finnish schools for all the pupils as part of the curriculum, alongside mathematics, Finnish, foreign languages etc. The music school system that is the topic of this article is distinct from these regular schools. To put it simply: everyone goes to regular school, and in addition, some go to music school in the afternoons to get further music education.
} 
Finnish music schools are now going through a curriculum change, and many of the problematic issues pointed out here have been addressed in the new curriculum framework (Opetushallitus, 2017a; 2017b). This study provides further knowledge for policymakers and music school teachers on the exclusive practices that students have faced, but also ways to create more inclusion, a joy of music and feelings of belonging.

\subsection{Research on Music Schools in Finland and Elsewhere}

Music students are most often researched in music education studies. The foci of these studies have been, for example, students' learning practices. For instance, Esslin-Peard \& Shorrocks, (2017) consider the differences in learning practices between British and Chinese university level music students. Dalagna (2016) has studied the effects of mentoring on desired artistic outcomes in music performance. Burnard's research (2012 \& 2013) concentrates on developing creativity in music education whereas Chaffin, Imreh, Lemieux, \& Chen (2003) study piano practice as expert problem solving. Another prevalent way of studying music students are questions relating to playing ergonomics (see e.g. Martín López \& Farías Martínez, 2013; Bruno, Lorusso, \& L’Abbate, 2008). The music institutions and their atmospheres and practices have hardly been studied at all. Closer to my approach are Rosie Perkins (2013a; 2013b) who has studied the effects of hierarchies in music education, and Alison Davies (2004) with an emphasis on the presumed meritocracy of music education. Henry Kingsbury (1988) has analysed in particular the role of talent in music education in a conservatory in the United States. The works of Perkins, Davies and Kingsbury are all ethnographic case studies at single institutions (see also Nettl, 1995 and Froehlich, 2002), and as such, rather narrow in scope.

It has been difficult to find comparable studies related to pre-college music education, because the differences between national education systems are notable. Music education institutions are not routinely studied internationally either (Perkins, 2013a). In the Finnish context the only somewhat comparable study is by Tuovila (2003), where she examines 7-13-year-old music school students ( $n=66$ ) and their views of studying in four music schools in Helsinki, as well as the musical practices in those institutions.

\subsection{On Meritocracy}


Literally, meritocracy means the 'rule of the merited' and refers to a form of government. It is a neologism coined by Michael Young (1958) in his book The Rise of Meritocracy. The principle, however, is much older; the idea of a society organized based on merit first appeared in Confucius' thought (Yearley, 2002, 247) and it can be argued that Plato (1999) and Aristotle (2005) also supported meritocracy. Nowadays, meritocracy manifests itself in meritocratic procedures, such as meritocratic selection in hiring or the general principle that people in higher positions ought to be there due to merit rather than because of money, influence or family connections.

With good reason, merit-based procedures of exclusion can be considered fair. The principle of merit is seen as a refusal of injustices (e.g., nepotism), and it reflects the ideal that all human beings are born equal (Girardot, 2011, p. 38). It justifies excluding those who do not fit certain criteria in a certain situation (i.e. who are not meritorious enough). For instance, it is clearly justifiable to exclude non-qualified surgeons from the operating room. From this commonplace understanding, however, things get more complex. Once meritocracy is introduced in a given situation, it makes exclusion available and justified. Exclusion is still a choice that concerns values, not a necessity. It may harm the excluded ones, and the risk of exclusion also affects those who are included.

An example of a meritocratic exclusion in music schools is the entrance examination: only people with certain merits (qualifications, propensities, abilities, characteristics, etc.) are accepted. Those who are excluded do not get the chance to learn the things the institution offers to those who pass the exam. The exclusion follows from an assessment of their potential. The excluded person is thought to not have what it takes to complete the education. However, this is not a fact but an assessment and a prediction. As an evaluator, Henry Kingsbury (1988) elegantly described this: 'I was ... asked not just for musical evaluation but for divination' (p. 64).

Meritocratic procedures and ethos relate to hierarchy (Rhodes \& Bloom, 2012). In principle, meritocratic procedures treat everyone as equals and individuals rather than as representatives of their families, for example. However, in meritocratic selections, the underlying thought is that everyone is not equal because the attempt is to select some over others. The goal of the procedure is to find out the differences between people that will (supposedly) determine who to justifiably hire for a given position or accept in a given institution. The hierarchy this creates is accepted as a given. Because the hierarchy is based on a meritocratic procedure, it is considered fair and unproblematic. Even if it is not-that is, if the people chosen by such a procedure prove to be unworthy of their 
position-it does not mean that the ideal of meritocracy and the hierarchy it is thought to be capable of justifying are questioned.

Rhodes and Bloom (2012) have argued that there is a cultural fantasy of hierarchies: 'Crucially, it is ... this constant disappointment [with inept people in power positions], which ironically organizes and reproduces us as subjects of desire to this cultural fantasy of hierarchy.' (p. 163). The same can be said of meritocracy, which Rhodes and Bloom list as one of the most important modern liberal and capitalist ideals. The apparent lack of merit in candidates chosen by a supposedly meritocratic procedure does not raise the question of whether power should be allocated by merit; it only proves that the process is biased. The ideals of justified hierarchy and meritocracy both only gain strength from failure. It is precisely because of injustice that it seems more important to try harder to realize true meritocracy. Meritocracy is considered inherently fair. However, the exclusion it justifies can still be problematic.

\subsection{Meritocracy in the Context of Music School}

In music schools, the meritocratic element is most visibly present in the form of the entrance examination. Also, those who succeed best in the course examinations get the best grades (Kangas \& Halonen, 2015). In addition to this, there is a tendency to divide the students into those with exceptional talent, the mediocre ones, and even those whose studies the institution wishes to cut short due to their poor results (Kangas \& Halonen, 2015, 204).

A meritocratic order is interpreted to be working if there is no clear conflict between the merits of the accepted and excluded: if the ones left outside are not, for instance, great musicians. If the results of the students shunned by the institution are bad and the ones who it appreciates are good, it is often interpreted as a logical consequence of the students' individual abilities, which the institution simply brings out. I wish to challenge this interpretation. It can be argued that the system of division and branding partly creates the differences in skills and reinforces original differences; in other words, it risks creating self-fulfilling prophecies.

Alison Davies (2004) has analysed the (supposed) meritocracy of one conservatory. She points out that middle-class students question the meritocracy less often than more mature students and students with a working-class background. They think that social factors also play a part in who is viewed as 'talented' in the conservatory. In accordance with this, my mostly middle-class 
respondents hardly question the justification of merit-based procedures, even when they see they do not benefit from them.

In this article, I argue that there are hierarchizing, merit-based practices in music schools. The hierarchies manifest, for example, in practices that exclude some students and include others. Although the hierarchies may be tacit, the students are aware of them and of their own standing in them. They interpret their standing in the hierarchy as a reliable assessment of their merits: their skills, level of talent, and/or potential. Due to being merit-based, hierarchies are considered justified, and hence the system of merit-based hierarchies is capable of producing self-fulfilling prophecies of the students' development.

\section{Research Questions, Data and Methods}

In a meritocratic framework such as an institution, inclusion and exclusion usually work through implicit or explicit hierarchies. Therefore, the research questions are:

1. What kinds of hierarchies, if any, are there in music schools?

2. What are the hierarchies based on?

3. How do the possible hierarchies affect the students' experiences of music school and possibilities of learning?

\subsection{The Data}

The survey data for the research project were collected during the late autumn of 2015 and winter of 2016. It was gathered online through a call for writings on a Jyväskylä University webpage, which was distributed mostly via Facebook and some mailing lists. The survey consisted of an introductory text, a short survey concerning background information and a space in which the respondents could recount their experiences. The scope of the inquiry was limited to the last 20 years, namely, to people who had studied in music schools during the years 1995-2015. There were 117 usable answers. ${ }^{6}$

\footnotetext{
${ }^{6}$ One respondent had not studied during 1995-2015, one did not indicate the time of study and considering their age had most likely not studied during that time. They were thus disqualified. One did not leave any background information, so their (short) answer was not considered.
} 
Sixty-nine per cent of the respondents were aged between 21 and 30. Only $12.8 \%$ of the respondents were men, so making conclusive comparisons between genders is not possible. Most of the participants (78.6\%) evaluated the income level of their family as middle, $18.8 \%$ evaluated it as low and $2.6 \%$ as high. Based on the families' income level and the respondents' and their parents' education level (Figure 1), it seems that respondents mostly came from middle-class or upper-class families.

Figure 1: Parents' education

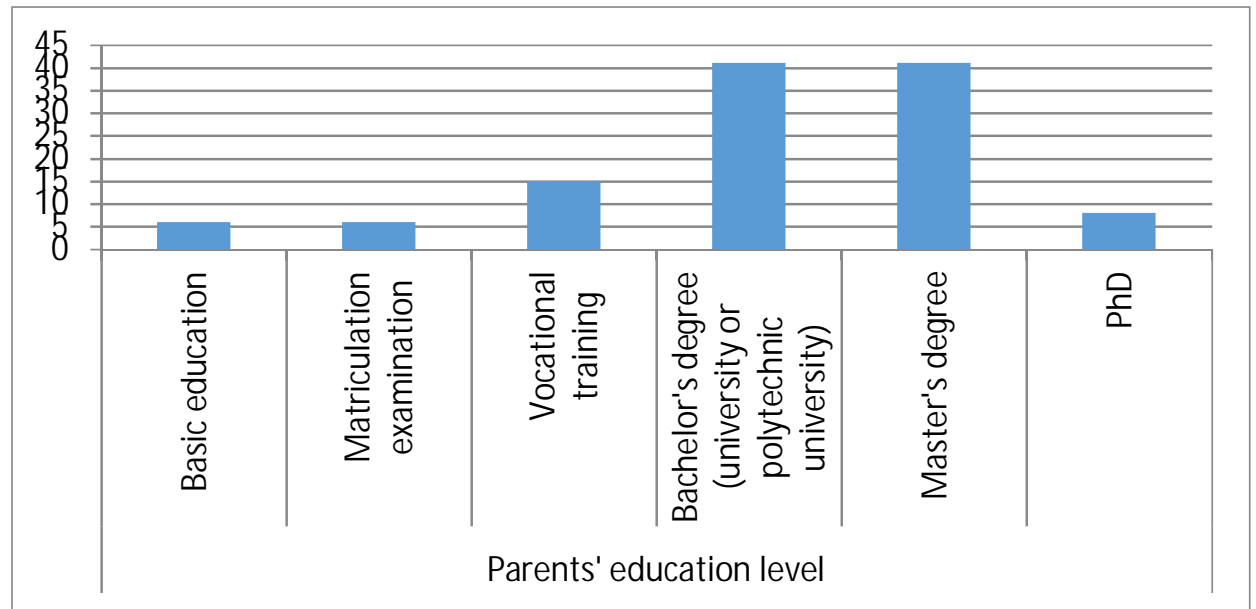

\subsection{Method}

The method of analysis was theory-driven qualitative content analysis (Alasuutari, 2012). As the theoretic foundation of the study, I have used my own framework of meritocracy, formed during my doctoral studies. The framework is based on the work of Dominique Girardot (2011), a French critic of meritocracy.

The creation of hierarchies is crucial to meritocratic practices (Elmgren, 2015; 2018; Girardot, 2011). Therefore, depictions of hierarchies were chosen as one theme of the analysis. In the content analysis, I coded the data according to specific traits and depictions of situations where the respondents felt excluded. In this article, I concentrate on the respondents' conceptions of 'talent' as a category that they invoke to explain and justify the division of the students into hierarchies, where the ones higher are more included in the practices of the school than the ones lower.

Exclusion does not come across as a simple matter in the data. Most responses recounted several, even conflicting, experiences of inclusion and exclusion. Someone who was well recognized and 
included by their instrument teacher could feel like an outcast during music theory lessons or in orchestra practice, or vice versa. Positive and negative feelings also seem to alternate during the years of studying in music school, due to, for example, the teacher changing or varying practices, such as voluntary activities becoming compulsory.

Studying experiences is not a self-evident task. The concept experience is not 'innocent'; it is already an interpretation by the person verbalizing their experience and by the researcher analysing it (Säilävaara, 2017; Saresma, 2010). I searched for depictions of different situations and practices that were related to inclusion and exclusion and classified them according to patterns that I was able to extract from them. Following Saresma (2010), my analysis aims at elucidating how the experiences of exclusion form, and what sorts of situations and practices are described in relation to exclusion. The longest and most reflective answers mostly came from people who had already ended their music studies some years ago. The temporal distance may have enabled them to gain more perspective on their years in music school, but it also means that questions of memory come into play. Also, some experiences may appear more meaningful after the studies have been completed.

\subsection{Limitations of the Study}

As the information and invitation to participate was distributed online, anyone fitting the description of 'studied in a Finnish music school between the years 1995-2015' was invited to take part. The survey was mostly distributed through Facebook, which means that most of the respondents were active Facebook users. The lack of male participation (less than 13\%) in the survey follows partly from the fact that fewer boys (approximately 1/3) than girls go to music school (Aluehallintovirasto, 2012). The majority of respondents represented middle or upper classes. To study the role of gender or social class in music school, another set of data collection is needed.

\section{Excluding Practices and Mindsets}

In Section 3.1, I track and classify the depictions of hierarchizing practices that the respondents have shared. In Section 3.2, I analyse how being considered talented can be invoked to work as a self-evident way to create a 'natural' hierarchy among the students. I trace how of being positioned and/or positioning oneself in the hierarchy affects the students' views of themselves as musicians, their motivation, and sometimes even career choices. 


\subsection{Hierarchies}

It would be easy to think of meritocratic exclusion simply in terms of who is accepted into the music school and who is not, on the clear basis of the exclusion of the entrance examination. Meritocratic exclusion, however, can continue after that through explicit and implicit hierarchybuilding. The ones included are higher in the hierarchy than the ones who feel excluded. Exclusion from higher places in the hierarchy is an ongoing, tacit process. Even without explicit exclusion, the process may lead a student to exclude themselves - with the result that they end their studies in the music school or conclude that becoming a professional musician is impossible for them.

Due to the connection between meritocracy and hierarchy (see Section 1.3), I wanted to study how the concept of hierarchy resonated with the respondents. I mentioned it in the call for writings, and $14.2 \%$ respondents wrote about it. In this section I have concentrated on studying whether the respondents had experienced hierarchies in music school and how the hierarchies were justified. According to Perkins (2013), the hierarchies of the institution and each student's position in them play an important part in 'what and how' the students learn. The chances of learning are thus very different for students who are higher and lower in the hierarchies. My findings provide further confirmation of Perkins' results and demonstrate how differences in opportunities develop already at early stages of music education.

According to the respondents, the hierarchies were based on differences in the perceived skills of the students. Due to this, I argue that hierarchies are meritocratic. The analysis shows that there are implicit and explicit hierarchies in music schools. The respondents were often aware of their own standing in them. The division into those who are included and those who are excluded was not necessarily (or even often) officially or explicitly made. Yet the perception of who was included and who was not was often, if not always, shared. The students higher in the hierarchies seem to gain confidence from their position, but for the ones who are lower, the opposite is true: both their confidence and motivation drop.

The hierarchies organize what Alison Davies (2004) calls the learning processes of the music school. In concordance with Davies' findings, also in Finnish music schools the ones who are left out of concerts or advanced orchestras are excluded from learning processes, meaning that they do not have access to all the educational opportunities the institution offers to the included ones. 
Hierarchies can be divided into four subclasses: 1) hierarchies among students of the same teacher (favouritism); 2) hierarchies among students who play the same instrument; 3) hierarchies on the level of the whole music school; and 4) hierarchies among teachers.

27-year-old Hanna explains the system of hierarchy between the students of their teacher: 'There was a clear hierarchy among the ... pupils: ... one ... [who] was to become a professional musician, the teacher's favourite; ... we, the good players... [who] competed for our place in the ranking; ... the unmotivated ones, who quit the hobby quickly; and the new beginners.' The respondent feels that the hierarchy stemmed from the 'teacher's attitude' towards the students.

Katja (aged 30) writes that her teacher had a favourite, a girl who was 'evidently talented', whom the teacher would put 'on a pedestal'. Three other respondents describe themselves as 'mediocre'. This may tell of a comparison between the students, but it also reflects their views of their level of talent or skills on a broader level.

The depictions of hierarchy are often static, like the ones above. Once established, the respondents seem to expect certain kinds of results of themselves based on their place in the hierarchy. Hierarchy thus seems to hinder the respondents' conception of their potential and prevents them from setting more ambitious goals.

Competition among the same teacher's students may widen to cover all the students of the same instrument. Lotta describes: 'I played in the best string orchestra of the music school', which indicates that not all string players were accepted as members of that group. Leeni mentions that 'the most demanding orchestras' had not included her when she was younger. The hierarchies of this level can also be created by the practice of allocating a certain level of students to certain teachers. Consequently, students make interpretations of their own place in the music school based on these divisions.

Hierarchies can be created not only in student/teacher relations but also by subtle, institution-level messages, such as the performance order of the players in student concerts. Several respondents from different music schools mention this, so the practice seems quite ingrained. The respondents interpret it as building a hierarchy between the students based on their current level of competence. 
Maiju describes: 'The magical performance order appeared on the wall and from that one can conclude the level of one's competence.'

In Tuovila's dissertation (2003), a nine-year-old girl told that she was the best in her group, because 'the one who plays last in a concert is the best of all'. She herself performed last, after a 'highschool student' (p. 172). The meaning of the performance order was already clear to this young student. Tuovila gives this as an example of the importance of peers and sees it as a possibility for creating healthy self-esteem.

Based on my analysis, the interpretations of these hierarchizing practices and their effects on students' self-esteem are more complex. In the data, finding oneself lower in the hierarchy is often experienced as discouraging. Milja describes her pride as, concert by concert, her place moved further towards the end in the order of performance: 'the most skilled one got the honour of being the last'. However, as her training motivation flagged, she had to witness younger students 'climb' past her in the order of performance. Her perception of her progress thus followed the order of performance. Milja reports starting to feel very nervous before performances and wonders whether it was due to her becoming a teen-ager or the fact that much younger students started playing same pieces as her. It seems arguable that her withering motivation and the competitive atmosphere of the institution created a situation where she did not have space to enjoy the performances like she had before. There is an expectation of maintaining a certain level and steady advancement by the institution and these overrule other meanings of the hobby.

Leeni, who saw herself as recognized in the music school, offered an explanation for always assembling the concert program so that the less difficult pieces are performed first and the more advanced later: 'Of course it might have reflected the level of advancement but it was also a practical thing.' The players at the beginning of the concert were younger and more nervous about their upcoming performance. This 'practical thing' also fits well with an attempt to build a dramatic arc for the concert, as Leeni puts it: 'The concert also always ended with a grand last number that was usually performed by the most advanced pupil.' These seemingly self-evident practices may have unforeseeable outcomes for individual students.

The most advanced students from the whole music school may also be asked to take part in joint activities, even outside the institution. For instance, Maria, a 19-year-old student, writes how the top-students 'with exceptional abilities, whose families ... had long roots in music ... quickly formed 
an "inside group/elite" in the music school'. The members of this group were always asked to perform at big concerts.

Leeni (aged 24) describes her positive experiences of having been able to 'hustle around [for instance, being asked to play on many occasions] as the best [player of that instrument] in the music school'. Leeni wonders whether the ones lower in the hierarchy were actually aware of the 'certain kind of ranking order' that prevailed in her music school. To her, it seemed that the ones 'lower in the ranking' were less interested in music and did not spend as much time at the music school as the ones higher in the ranking. "Now that I think about it, it might have been because of the ranking ... I remember thinking that those less integrated in the music school world probably didn't know who was ... "good" and who was "bad".' The recollection of Maria (aged 19) points to the opposite: 'No one would say these things out loud, but I know it [the division of students in groups that were treated very differently] caused problems, not just for me but for many others.'

In four cases from four different music schools, a respondent refers to a ranking order of teachers that manifested itself in the way that the students were divided among different teachers. Within the scope of this study, it is not possible to know whether such rankings really existed and whether the teachers were aware of them or not. Nevertheless, some students interpreted the system of giving the 'best' students to certain teachers as signifying a ranking order among the faculty.

In some cases, the students interpreted having a certain teacher as a sign of their own place in the hierarchy. Inka writes: 'There were a few "elite teachers" in the music school-my teacher was not one of them but in practice this person was just right for me.' Interestingly, two other respondents from the same music school had similar experiences and interpretations: Maiju had 'concluded that the teachers had been ranked by their skills and then we the students were divided to different teachers, according to our skills'. This interpretation affected her view of herself as a musician: 'As I was never accepted as the student of that teacher whose students did so well in concerts ... I concluded I am not good at playing the piano.' Suvi, from the same music school, describes: 'Certain teachers in the music school were profiled as more recognized as others and being their student was a merit.' In another music school, Mikael tells that 'everyone silently knew' that the 'best students' were allocated to a certain teacher.

\subsection{Talent as a Condition for Inclusion}


Talent refers to special aptitude (as in artistic or athletic talent) that is often thought to be innate or 'natural', as in the Cambridge English Dictionary's definition: 'a natural ability to be good at something, especially without being taught' ('Talent' 2018). The music school students who advance most quickly are often considered talented and, the other way around, the ones advancing less quickly are thought to lack talent. I wanted to study how respondents relate to the concept of talent. Therefore, it was asked in the call for writings whether the respondents had felt that their 'motivation, application and talent were recognized' in the music school.

The concept of talent as an innate merit that cannot be learned or changed (as seen in the definition above) may pose a threat of limiting a subject to factuality, as Dominique Girardot calls it (Girardot, 2011, 130-132; see also Elmgren, 2015). Subject here refers to any person; being limited to factuality means that the subject is considered only based on what they are able to do and produce now. The subject becomes limited to the 'factual' evidence of their abilities, such as test results, performance in an audition, and the way they sing or perform at this moment.

The limiting of a subject to their factuality resonated with some of the of the respondents' texts. One respondent reports thinking that not being able to 'get cadenzas' meant she was not fit to become a professional musician. She takes factual inability or difficulty in one part of the musical practice as a sign of permanent failure and the impossibility of reaching a meaningful goal; this single factual obstacle affects her view of her whole potential, in the sense of potential abilities and potential futures. Not doing well in music theory led two respondents to get negative feedback from their theory teacher regarding their abilities in music in general. The teachers have taken the particular difficulties that their students are facing as signs of general inability. In this mind frame, current problems are understood as more general indicators of the student's musical abilities and potential instead of concrete issues that can be solved by practice.

Most of the respondents who talk about talent write about it in relation to advancing and learning quickly, or playing well. Similarly, the ones who feel they lack talent simply write about 'not being good enough' and therefore not having a chance of becoming a professional. Or, like one respondent, they state as a fact that 'there were a lot more talented students among the ones a couple of years older than me'.

In the data, the conclusions drawn by those who talk about talent are similar. The thought of oneself as talented may be an important psychological resource for some students (5.8\%): Katja protests 
what she sees as unfair judgment, appealing to actually being talented, 'Goddammit!' For Suvi, for instance, being considered as a part of the most talented 'caste' of students was a 'major motivational factor'.

On the other hand, $8.3 \%$ mention thinking of themselves as not talented enough, as average or mediocre players, or having a low consideration of their level of musicality. This does not have to be a problem. Reetta tells that 'being average was enough for me', as her main ambitions were elsewhere, in sports: 'In music I was average and ... the point was to get joy out of doing it.' However, for most who write about their perceived lack of talent, being considered average or 'not amazingly good' caused problems and made it more difficult to see reaching certain goals as possible. It is notable, however, that even for those for whom the lack of talent is not a problem or who note that a lack of practice also has something to do with their level of success, it still seems that having more talent would be a reason to practice or invest more in music.

The feeling of inadequacy can persist through years of training and advancing to the professional level. Katja (aged 32) has a professional degree in her instrument, but as a child she was rejected by the entrance examination board and finally started music school when she was sixteen. Despite her diploma and years of training, she ends her text with a sceptical reflection of her abilities: 'On the other hand, despite my plans I did not end up as a professional musician, so maybe the selection board of music school was, in the end, right then, 25 years ago.' The ending can be read as a sign of a sort of talent-related determinism: if someone is meant to 'make it', it is clear from the beginning; no amount of training will change it. Not becoming a professional musician is explained in rather a meritocratic way: Katja seems to suppose that the ones now working as musicians have been somehow better than her from the start. Only seeing personal effort and talent as explicating factors for any situation is typical of meritocratic logic: other explanations can be excluded, such as the realities of working life, the significance of connections, economic situations and so on (Girardot, 2011). Completely against this deterministic and meritocratic logic, right before her pessimistic conclusion, Katja tells that during her music school years, she noticed 'with some schadenfreude' that she was suddenly treated as a 'gold student' in the same institution that had originally rejected her. Katja seems to have made an impression on the music school staff: 'I think someone in a higher position commented [on rejecting her earlier] in an embarrassed tone.' This indicates it had become clear that the rejection had been a mistake. It is curious that in spite of all the recognition and personal success, Katja ends her text by wondering whether that rejection might have been justified. 
It seems that the beliefs and myths relating to what musical talent is are stronger than any evidence presented to the contrary.

Another respondent, now working as a professional musician, 28-year-old Mikael, also reports still suffering due to harmful attitudes related to musical talent. Only now, with new experiences in improvised music, has he started to see himself as musically talented: 'During my music studies I developed a conception of myself as very unmusical.' He sees the teachers' attitudes as crucial in the development of this self-conception. His first music theory teacher hinted for several years that 'not everyone's abilities will be enough in the long run'. The teacher seems to have thought that these abilities are not something that are learned but are innate. Kangas and Halonen (2015, p. 204) point out that sometimes teachers may try to end the studies of slowly advancing students by encouraging them to stop. Mikael experienced something like this due to his lack of practising during the first years at music school: 'also my own instrument teacher ... suggested several times I should change [instrument] or maybe start Boy Scouts instead...' When his practice motivation got better, the teacher also changed his or her attitude and became encouraging. However, the earlier negative experiences were not effaced by this new attitude and encouragement. Mikael writes: 'Insinuations like this still have an effect on me as I work as a professional musician, wrecking my self-esteem from time to time.' Mikael's and Katja's examples show that success in studies does not equate feeling included or guarantee freedom from harmful thought models.

The relationship between talent and motivation seems an interesting one. Many respondents reported of not being or not having been motivated to practice. On the other hand, positive comments about music school teachers often described the teacher actively motivating the student. It thus seems, that some teachers may take the lack of motivation as a given, whereas others try to affect the student's motivation. In the case where the teacher does not try the motivate the student, the lack of motivation to practise and consequently not developing musically may lead into a situation where the teacher, parents and/or the student interpret not advancing as a further proof of lack of talent, such as in the case of Mikael.

Being considered talented often means having privileges and special attention from the teachers. However, in a few cases, the respondents frame talent as an external force that someone else, rather than the student, sees as compelling. Talent becomes something that needs to be actualized: it becomes the reason to pressure the student to study too much (by the parents and/or instrument teacher). Niina (aged 24) describes it thus: 'Being talented, advancing became more of an 
obligation.' Three respondents write about being considered good and talented musicians, but not enjoying music anymore. At worst, the student considered talented may be expected to dedicate their life to music simply because they are talented. Talent becomes a reason to instrumentalize the students.

\section{Discussion: Meritocracy as Production of Failure}

Meritocratic exclusion works by granting opportunities to those who are perceived as worthy of them, that is, who merit them. In the context of an educating institution, it means exclusion from certain learning practices, as Alison Davies has formulated, which is also visible in my data. In the music schools, this is framed as rewarding the best students for their advancement.

My analysis shows that there are implicit and explicit hierarchies in music schools in Finland. This shows that hierarchies can start to develop at the earliest stages of music education. Furthermore, the dynamics related to hierarchies and meritocracy observed in the higher levels of music education (Perkins, 2013a; Davies, 2004) manifest already in education for children and the young. The hierarchies are created by subtle institutional messages, such as performance order in concerts, by including only certain students in performances, by creating orchestras based on the level of players' skills and by the teachers' words and attitudes. In some cases, teachers tried to avoid fuelling competition among students, but the structural practices and persistent and pervasive mindsets still enabled the students to create comparisons amongst themselves.

The hierarchies are based on perceived merits, that is, the skills and abilities of the students. However, based on my analysis, it can be argued that the hierarchizing practices and thought models accompanying them accentuate the original differences. They encourage and motivate the ones deemed more 'talented' than their peers and discourage the rest.

Based on the way the respondents write about talent, I would argue that talent becomes a tool for meritocratic logic, which helps justify exclusion. Talent is a fact-like quality, not something one can develop, as it is considered innate and natural. Concentrating on talent may become an instrument of limiting a subject to one's factuality. If one is considered factually to possess talent (e.g. being told they have 'potential' or 'talent', which means this 'factuality' may be very vague and nontangible), it works as a psychic bulwark ${ }^{7}$ that may protect its possessor from some of the harm inflicted in a meritocratic environment. Inversely, if one is considered factually not talented, it

\footnotetext{
${ }^{7}$ On 'ideology of merit' as a psychic bulwark against life's precariousness, see Girardot 2011.
} 
becomes a permanent feature of the person. Based on my data, the students may believe that their place in the hierarchy is a fact about themselves. The talent framework seems to provide no tools to tackle one's difficulties but instead demands one to accept them as an unavoidable fate (see also Esslin-Peard \& Shorrocks, 2017).

Exclusion from concerts, longer lessons and special attention is justified by meritocratic logic, according to which the best ought to be rewarded and given the most possibilities and rewards for their advancement. In practice, it means excluding some students from learning opportunities. This is how meritocracy can in fact produce the failure it pretends only to reflect.

The practices at a music school may well be meritocratic and reflect true differences in skills of the students. It may be that the ones highest in the hierarchies are the best players as well. This can, however, be achieved by not allowing all students to acquire the all needed abilities. As mentioned, the respondents often complimented their teachers for motivating them. This means these teachers did not take motivation as a given and it may have allowed more students to be able to find their personal motivations to practice and develop their skills. This is yet another example of how differences in skills may be the result of the music school practices rather than reflect innate differences of the students, such as talent.

In the light of these remarks, meritocratic processes start to seem dubious. The question is, therefore, not how to improve the working of the meritocratic processes, but how to enable everyone to have access to all the learning processes at a given educational institution.

\section{Appendix: Call for Writings (translation from Finnish)}

\section{Beta blockers before student concerts or the key to finding your own field?}

Have you studied in a Finnish music school during the years 1995-2015? I'm collecting research data on Finnish youth and young adults' experiences of music school for my dissertation in which I study meritocracy.

In meritocratic practices, such as aptitude tests, competitions and hierarchies that are based on these, the crucial thing is the possibility to exclude some (not showing merits) and include some (with merits). One gets into music school through an entrance examination. This means that for the ones who get in, the first possible exclusion has been passed. Some students end up as professional musicians and some quit their studies during their teenage years and refuse to touch their instrument for years, if ever. What happens during 
the time in music school? Puberty alone cannot be the explanatory factor, as it does not deter all beginning musicians.

I examine inclusion and exclusion that take place in the music school. I'm looking for accounts of both nice and unpleasant experiences in music school. Which factors played a part with what happened to you and your music hobby? Which practices in music school and ways of studying music motivated you to continue the hobby? Did some practices or ways of studying affect the practising motivation negatively? What kind of conception did you develop of yourself as a musician during your studies?

In music schools, students may be encouraged to advance in their music studies in many different ways. The most advanced students may be rewarded with, for instance, encouragement grants, possibilities to perform, longer lessons and master classes given by special teachers... Were these kinds or other types of encouragement used in your music school? How did you experience these practices, and did you get to be involved in them or were you left outside?

Was there competition or (explicit or implicit) comparison among the students in your music school? What was the teachers' part in creating the atmosphere in the music school? Were they aware of possible competition? Did you feel that your motivation, application and talent were recognized and that you could advance in your music studies in the way you wished?

Write freely about your experiences. The writing may be a short description of a single situation or an incident linked to music studies, or it can be a wider text, charting your life, music as a hobby and music studies. I am asking all the writers to also fill out the preliminary information form, which seeks background information that is important for the study. If you wish, you may also leave your contact information in the preliminary information form. Among those writers who leave their contact information, there will be a lottery of 15 movie tickets as a prize for writing.

\section{References}

Alasuutari, P. (2012). Laadullinen tutkimus 2.0. Tampere: Vastapaino.

Bruno, S., Lorusso, A., \& L'Abbate, N. (2008). Playing-related disabling musculoskeletal disorders in young and adult classical piano students. International Archives of Occupational and Environmental Health, 81, 855-860.

Burnard, P. (2012). Musical Creativities in Practice. Oxford: Oxford University Press. Burnard, P. (2013). Developing Creativities in Higher Music Education: International Perspectives and Practices. London: Routledge. 
Chaffin, R., Imreh, G., Lemieux, A., Chen, C. (2003). "Seeing the Big Picture": Piano Practice as Expert Problem Solving. Music Perception, 20, 465-490.

Dalagna, G. (2016). Resultados Artísticos Desejados Na Performance Musical: Um Programa De Tutoria Para O Ensino Superior E Indústrias Da Música - Desired Artistic Outcomes In Music Performance: A Mentoring Program For Higher Education And Music Industries. Doctoral dissertation. Universidad de Aveiro.

Davies, A. (2004). Preparing professional performers: Music students' perceptions and experiences of the learning process at Birmingham Conservatoire. International Journal of Qualitative Studies in Education, 17, 803-821. Retrieved from (accessed 18 June 2018): $<$ https://www.tandfonline.com/doi/full/10.1080/0951839042000256466?scroll=top\&n eedAccess $=$ true $>$

Elmgren, H. (2015). Recognition and the Ideology of Merit. Studies in Social and Political Thought. Sussex: Brighton Students and Faculty of the Graduate Programme in Social and Political Thought, University of Sussex. Retrieved from (accessed 18 June 2018):

<http://journals.sussex.ac.uk/index.php/sspt/article/view/32>

Elmgren, H. (2018). Merit, competition, distinction. Redescriptions: Political Thought, Conceptual History and Feminist Theory, 21, 71-89. Manchester: Manchester University Press.

Esslin-Peard, M. \& Shorrocks, T. (2017). Using Reflection to Develop Insights into Musical Practice and Performance: A Pilot with Chinese M Mus Students. A conference presentation at Hull Musical Cultures Conference, 3 April 2017.

Froehlich, H. (2002). Thoughts on schools of music and colleges of education as places of 'rites and rituals': Consequences for research on practising. In I. M. Hanken, S. G. Nielson, \& M. Nerland (Eds.), Research in and for higher music education: Festschrift for Harald Jørgensen (pp. 149166). Oslo: Norges Musikkhøgskole.

Girardot, D. (2011). La société du mérite: Idéologie méritocratique \& violence néolibérale. Lormont: Le Bord de l'Eau.

Kangas, A. \& Halonen, K. (2015). Taidekasvatuksen ja -koulutuksen tavoitteet ja haasteet. In I. Heiskanen, A. Kangas, \& R. Mitchell (Eds.) Taiteen ja kulttuurin kentät (pp. 191-230). Helsinki: Tietosanoma. 
Kingsbury, H. (1988). Music, talent, and performance: a conservatory cultural system. Philadelphia : Temple University Press.

Martín López, T. \& Farías Martínez, J. (2013). Strategies to Promote Health and Prevent Musculoskeletal Injuries in Students from the High Conservatory of Music of Salamanca, Spain. Medical Problems of Performing Artists, 28, 100-106.

Nettl, B. (1995). Heartland excursions: Ethnomusicological Reflections on Schools of Music. Urbana: University of Illinois Press.

Opetushallitus (2017a). Taiteen perusopetuksen laajan oppimäärän opetussuunnitelman perusteet. Retrieved from (accessed 7 May 2018):

<http://www.oph.fi/download/186920_Taiteen_perusopetuksen_laajan_oppimaaran_o petussuunnitelman_perusteet_2017.pdf>

Opetushallitus (2017b). Taiteen perusopetuksen yleisen oppimäärän opetussuunnitelman perusteet. Retrieved from: (accessed 7 May 2018):

<http://www.oph.fi/download/186919_Taiteen_perusopetuksen_yleisen_oppimaaran_ opetussuunnitelman_perusteet_2017.pdf>

Perkins, R. (2013a). Hierarchies and learning in the conservatoire: 'Exploring what students learn through the lens of Bourdieu'. Research Studies in Music Education, 35, 197-212.

Perkins, Rosie (2013b). Learning Cultures and the Conservatoire: An Ethnographically-Informed Case Study. Music Education Research, 15, 196-213. Taylor and Francis Online. Retrieved from (accessed 18 June 2018):

<http://www.tandfonline.com/doi/full/10.1080/14613808.2012.759551?scroll=top\&ne edAccess $=$ true $>$

Rhodes, C. \& Bloom, P. (2012). The Cultural Fantasy of Hierarchy: Sovereignty and the Desire for Spiritual Purity. In T. Diefenbach, \& R. Todnem (Eds.) Reinventing Hierarchy and Bureaucracy from the Bureau to Network Organizations, (pp.141-169). Bingley: Emerald Group Publishing Limited.

Riediger, M., Eicker, G., \& Koops, G. (2010). Music Schools in Europe - Musikschulen in Europa - Les écoles de musique en Europe. (A report by the European Music School Union.) Retrieved from (accessed 18 June 2018): 
$<$ http://www.musicschoolunion.eu/wp-

content/uploads/2016/08/101115_EM_publicatie_EMU_2010_digitaal.pdf>

Saresma, T. (2010). Kokemuksen houkutus. In Tuija Saresma, Leena-Maija Rossi, \& Tuula Juvonen (Eds.), Käsikirja sukupuoleen (pp. 59-74). Tampere: Vastapaino.

Säilävaara, Jenny (2016). Imettämässä kaapissa? Pitkään imettäneet äidit ja normatiiviset tilat. Sukupuolentutkimus, 29, pp. 7-20. Tampere: Sukupuolentutkimuksen seura Sällskapet för genusforskning r.y. (SUNS).

Tuovila, Annu (2003). "Mä soitan ihan omasta ilosta!” Pitkittäinen tutkimus 7-13-vuotiaiden lasten musiikin harjoittamisesta ja musiikkiopisto-opiskelusta. Doctoral dissertation. Studia Musica 18. Helsinki: Sibelius Academy. Retrieved from (accessed 18 June 2018):

<https://www.edu.helsinki.fi/lapsetkertovat/lapset/Tutkimus/Annu_Tuovila.pdf>

Young, Michael (1958). The Rise of Meritocracy, 1870-2033. Westminster: Penguin Books.

\section{Laws cited:}

Law concerning government subsidies 2001/688 (Valtionavustuslaki). Decreed in Helsinki, 27 July 2001. Retrieved from (accessed 18 June 2018):

<http://www.finlex.fi/fi/laki/ajantasa/2001/20010688\#L2P5 >

Law concerning the basic education of arts 1998/633 (Laki taiteen perusopetuksesta). Decreed in Helsinki, 21 August 1998. Retrieved from (accessed 18 June 2018):

<http://www.finlex.fi/fi/laki/ajantasa/1998/19980633?search[type]=pika\&search[pika] $=$ taiteen $\% 20$ perusopetus $>$

\section{Webpages:}

Alt, Sanna, Enakimio, Kaisa, Meriluoto, Satu, \& Rodionoff Niina 2017. Finnish National Agency for Education webpage: <www.oph.fi> (accessed June 18 2018)

Suomen Musiikkioppilaitosten Liitto 2017. Webpage: 〈http://www.musicedu.fi>

'Talent' 2018. Definition from Cambridge Dictionary. Retrieved from: https://dictionary.cambridge.org/dictionary/english/talent\#british-1-1-1 (accessed 19 December 2018) 